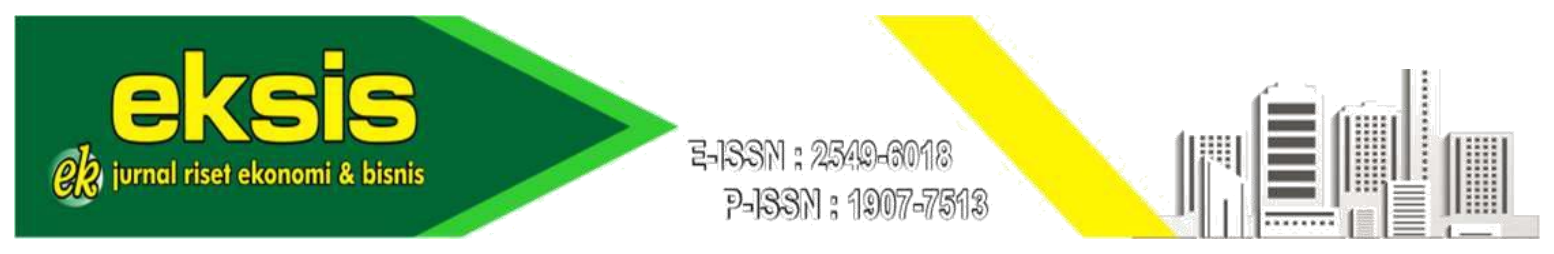

\title{
Leadership Should or Should Not Delegate Communication? (A Systematic Literature review: The Art of Delegation)
}

\author{
Gibriel Badjie \\ The University of the Gambia \\ gbadjie@utg.edu.gm
}

Submitted: December 5, 2020, Revised: January 10, 2021, Published: March 5, 2021

\section{Abstract}

Communication and delegation are two important and parts of the leadership function. However, it is still a matter of debate whether leaders can delegate responsibility for communication, especially policy information, to those under their authority. Various opinions state that there is no prohibition for leaders to delegate their responsibilities because this is the leader's prerogative. This study aims to identify whether leadership should or should not delegate communication. The method used in this study was Systematic Literature Review (SLR). The SLR method is used to identify, review, evaluate, and interpret all available research by topic area phenomenon of interest, with specific relevant research questions. The results showed that leaders can delegate communication but it is highly dependent on the type, style, and approach of leadership on the table at that time. Such a leadership style or approach will automatically influence the style and approach of communication and delegation.

Keywords: Communication, Delegation, Leadership, Leadership communication; Delegation of leadership

\section{A. INTRODUCTION}

For a leader, communication and delegation can help achieve efficiency and effectiveness. Delegation is an interactive process between two or more people who share moments of mutual understanding to turn results-oriented efforts into real-life goals. The art of delegation is from superiors to those in lower ranks (subordinates) in work to achieve mutually beneficial goals.

Leadership is about guiding others into the future (vision). Leadership does not operate in a vacuum and isolation from others. Leadership requires the participation and involvement of others because leaders themselves with all their strengths cannot and will not be able to get the desired results for the future. Leadership occurs through a process of interaction and communication (Hamrin, Johansson \& Jahn, 2016). Leadership requires a change both from those who govern and those who are governed.

Leadership is largely defined and closely related to influence. The influence of leadership must be visible in the short and long term. Short-term leadership influences try to influence short-term gains while long-term leadership influences must be able to bring about change. The long-term goal of leadership is to create positive change through real communication efforts. Leadership requires influence and obedience, but the most important task is to win the hearts and minds of those who are subordinate. This is where communication is needed.

Communication is not only a critical leadership skill but also a manifestation of leadership. The leader's ability to communicate well and convey his message to his followers will always result in a strong bond. Communication between leaders and members creates strong social relationships (Zulch, 2014). This type of relational bond is described by Hon \& Grunig (1999) as a communal relationship, namely a relationship 
in which the parties are willing to provide benefits to the other party because they pay attention to the welfare of the other party. The quality of the relationship is characterized by mutuality control, trust, commitment, and satisfaction.

Leadership communication must be measured. This means that leadership communicates when it matters most because when leaders communicate, the rhetoric is in line with policy implications. Communication can mark a leader, enhance his image, and enhance the reputation of his leadership as a trusted and dependable person. The leader's communication can lead to a lack of credibility and the respect earned.

From the description above, the formulation of the problem raised in this study is to find out whether leadership should or should not delegate responsibility for communication? And, what are the implications of the delegation?

In this study, data were collected from research information about the type of leadership and leadership style about communication responsibilities and their implications from 1999 to 2019. These data were identified using the Systematic Literature Review (SLR) method. With the use of the SLR method, can be reviewed and systematic identification of journals which in each process follow the steps or predefined protocols. Besides, the SLR method avoids identification which is subjective in nature and it is hoped that the results of its identification can add to the literature on the use of the SLR method in journal identification.

\section{B. LITERATURE REVIEW}

A delegation is a form of time management. This is a way of exercising control and fulfilling leadership responsibilities more effectively while delegating subordinate skills (Yukl \& Fu 1999). Delegation and communication are recognized as important because leadership skills can make a person successful. Delegation as an interactive phenomenon cannot occur without effective communication. According to Kovac \& Jesenko (2010), delegation, communication, and control are key elements of the leadership process and the level of democracy in an expanded leadership style determines the level of formalization in the delegation, communication, and control.

Delegation is an important management tool (Ayres, 1992) and is an activity with authority and responsibility (Axley, 1992). Delegation is also a function of the arts and skills of a leader to help empower subordinates (Kovac \& Jesenko, 2010). There are a limited number of studies linking delegation to communication. According to Dessein (200 2), delegation increases development and efficiency for subordinates and leadership. Therefore, effective delegation is very dependent on effective communication.

Delegation benefits leader-member relationships increases the speed and quality of decision making, reduce the workload for the leader, enriches the knowledge and skills of subordinates. Delegation is as old as management concepts and is concerned with employee engagement, empowerment, decentralization (Yukl \& Fu; 1999).

Communication is a process that cannot be delegated. Communication is the only phenomenon labeled as leadership functions, processes, skills, tasks, and responsibilities. Many articles illustrate that in an organization's hierarchical communication structure, supervisors as middle leadership relate and are more in line with employee communication needs than direct leadership. Supervisors are more trusting and credible than leadership because they have strong bonds, attachments, engagement, and involvement due to the closeness of content and work context. 
Therefore, supervisors fit the responsibilities of a third-party spokesperson to handle delegated communication responsibilities (Men, 2014).

An effective team requires a reliable communication process, with clear responsibilities and appropriate delegation (David, 2016). Communication is the whole of the organization's existence; it is larger in scope than delegation and can also be narrowed down to specific user needs. According to Kovac \& Jesenko (2010), both communication and delegation can be done formally or informally as well as through written or oral means as well as through third parties. In essence, both communication and delegation can be passed on through colleagues.

Organizational communication according to Badjie, Thoyib, Hadiwidjojo \& Rofiq (2019) has three different dimensions, namely leadership level communication, functional level communication, and operational level communication. Thus it is emphasized that leadership communication must occur between Mintzberg's (1971) managerial roles and interpersonal roles. The informational role is referred to as the information communication role and the decisive role is referred to as the decision communication role. According to their argument, leadership should not delegate communication which is the primary responsibility of leadership. But others argue that nothing is off-limits when it comes to delegation. Even planning, main managerial functions, or leadership functions are often delegated and in some organizations, there are offices designated for assistance and leadership. Communication like planning in most organizations has designated offices with Public Relations professionals who assist the leader in public or stakeholder engagement issues through targeted communication efforts.

There is a big difference between the need for and consumption of internal communication and the need and consumption of external communication. Organizational internal communication is related to policy guidelines, directions that are deliberately carried out to influence, to obtain compliance from subordinates to achieve goals. The messaging aspect of internal communication must resonate with employees' emotions. In this sense, internal communication requires and demands leadership visibility because the leadership personality is a big part of the picture. Winning hearts and minds demands intense engagement and engagement for chain dependency recognition and consideration. Organizational external communication is mostly done deliberately to build and maintain good sustainable relationships with outsiders. Communication here needs to be done so that it is aligned with the organization's strategy to impress, build a long-lasting image and reputation. The leadership role is important here as the face of the organization, but Public Relations professionals are better suited to carry out this function on behalf of the organization better. Communication delegates for external engagement are accepted and expected as thirdparty public relations practitioners as the main spokespersons to serve the organization well.

The majority of spokespersons first received direction from the leadership regarding important points discussed regarding external stakeholders. They are trained experts in the art of communication, media relations, with expertise in polishing an organization's image and brand.

Being a spokesperson is not easy. The world of spokespersons or third-party communicators lives between two worlds that are often criticized, namely deception or propaganda on behalf of the organization and its leaders. A sincere spokesperson seeks to be himself rather than the embodiment of leadership. It is selfless responsibility to 
cloak the image, personality, and character of leadership. Being a spokesperson means being a strong ally of the leadership, seeing and not hearing mistakes when it comes to leadership. the main task is to turn negative news into positive news for the organization and its leadership. A spokesperson must be a loyal servant of the leader not yet true to his conscience. Credibility is a key character most guarded by all spokespersons as they reveal the organization's official talking points. They must have the critical and astute ability to advise leadership with honesty and integrity. Delegation of communication is more likely and preferable in external communication than in internal communication.

According to Garofalo \& Rott (2017), the bad news is very difficult and challenging to convey because of its unpleasant nature which involves embarrassment and the personal pressure it will cause. Leadership in an uncomfortable situation to make unfair or unpopular decisions that must be communicated to affected people prefers to excuse himself to avoid the emotional distress provoked by communicating bad news, preferring to delegate the task to third party spokesperson to deliver bad news, unpleasant news to a safe face. Such delegation of communication responsibilities is planned strategically to divert mistakes or reduce the consequences of mistakes and take responsibility for what may happen after the delivery of such a bad decision.

In line with that, it is emphasized that in bad decision news communication, the communication style should express emotions or rationality based on the situation and the affected party. But what communication style is needed if delegated communication decisions are good news. Leadership has three choices about delegating responsibility, no delegation, voluntary delegation, or mandatory delegation and each of them has its consequences. Much of the honest and authentic way of delegating offensive communication decisions will depend largely on the style of communication. Quite often, recipients feel offended when the communication style shows deep emotional remorse that shows empathy and is in line with people's feelings. This approach does not attract punishment, there is no grudge and people will not be bitter because they will attach bad faith symbolism to the whole situation (Garofalo \& Rott, 2017).

In today's organizational settings, many large organizations have public relations departments that are tasked with organizational communications. Public relations personnel serve as funnels for leaders for internal and external communication to bring positive changes that are beneficial to the organization. Nevertheless, in the same organizational setting, it is argued that the leader must be the spokesperson for the organization in matters that are essential to the organization's profitability, growth, and survival. It is also common to accept different and conflicting views coming from the same institution through different sources. Communication is related to leadership and can vary as a function of the context, the goals to be achieved, both for individuals and groups with whom the leader works.

There is a strong relationship between leadership and communication and leadership and delegation. Some see both delegation and communication as important skills or processes in leadership. Communication is one of the most dominant and important activities in organizations as it is often referred to as tasks, skills, processes, functions, and responsibilities.

Delegation in a relational context with an approach requires the use of appropriate words and styles to engage the person in view to get obedience to achieve results. Delegation is the prerogative of leaders and delegates that are approved by a need-based on unique circumstances. Leadership delegation involves an efficient transfer of work to people whose skills are better suited for the task. The leader delegation enhances others 
to have the skills and abilities essential to be good and productive team members. These leadership actions empower, motivate, develop self-efficacy and self-confidence in subordinates. Communication and delegation by implication provoke interactive $\mathrm{d}$ by the implications involved in the engagement process. Delegation and communication are multifaceted phenomena capable of shaping leadership. For leaders, delegating is a responsibility and maybe a mandatory requirement to engage, involve, empower, decentralize, and manage others as team members.

Many research studies have been conducted to describe the convergence of leadership and delegation, but there is no substantive study of whether leaders should delegate each responsibility. And if there is, whether the leader should delegate or not delegate communication. The leader influences other members to achieve the desired goals. But influence alone will not be enough to change people towards the desired behavior. Leaders who influence and gain the obedience of subordinates/followers are those who have a bigger role in the followers. The leader's ability to achieve follower compliance can be achieved through measurable communication.

Important words in communication. The essence of speaking with one voice and one general message through a reliable source makes a huge difference in winning others' hearts toward change. Delegation is the prerogative of the leader while communication is the responsibility of the leader who is important in determining leadership effectiveness. Different types of leadership, leadership styles, leadership approaches, and characteristics have different orientations when delegating communication.

In table 1 below, various types of leadership are presented and their relationship to communication tolerance and delegation tolerance from previous researchers

Table 1: Types of Leadership

\begin{tabular}{|c|c|c|c|c|c|c|}
\hline $\begin{array}{l}\text { Leadership } \\
\text { type }\end{array}$ & Meaning & Characteristics & Approach & $\begin{array}{l}\text { Tolerance of } \\
\text { communication }\end{array}$ & $\begin{array}{l}\text { Tolerance } \\
\text { of } \\
\text { delegation }\end{array}$ & Author \& Year \\
\hline $\begin{array}{l}\text { Transformat } \\
\text { ional } \\
\text { Leadership }\end{array}$ & $\begin{array}{l}\text { Broaden and } \\
\text { elevate the interest } \\
\text { of followers, } \\
\text { generate } \\
\text { awareness and } \\
\text { acceptance of } \\
\text { purpose and } \\
\text { mission }\end{array}$ & $\begin{array}{l}\text { Idealized influence, } \\
\text { Inspirational } \\
\text { motivation, } \\
\text { Intellectual } \\
\text { stimulation \& } \\
\text { Individualised } \\
\text { consideration }\end{array}$ & $\begin{array}{l}\text { Participatory, } \\
\text { Empowering, } \\
\text { People- } \\
\text { motivated, } \\
\text { Relationship- } \\
\text { oriented and } \\
\text { Consideration } \\
\text { Approach }\end{array}$ & $\begin{array}{l}\text { Open \& } \\
\text { transparent } \\
\text { communication }\end{array}$ & delegate & $\begin{array}{l}\text { Zareen, Razzaq \& } \\
\text { Muitaba (2015); } \\
\text { Men (2014) }\end{array}$ \\
\hline $\begin{array}{l}\text { Transactional } \\
\text { Leadership }\end{array}$ & $\begin{array}{l}\text { Centered on } \\
\text { leader-follower } \\
\text { exchange } \\
\text { relationship. } \\
\text { Follower act in } \\
\text { line with the will } \\
\text { \& directive of the } \\
\text { leader }\end{array}$ & $\begin{array}{l}\text { Contingent reward, } \\
\text { Active management } \\
\text { by exception \& } \\
\text { Passive management } \\
\text { by exception }\end{array}$ & $\begin{array}{l}\text { The directive, } \\
\text { Production- } \\
\text { Oriented, Task- } \\
\text { Motivated \& } \\
\text { Structure } \\
\text { approach }\end{array}$ & $\begin{array}{l}\text { Close \& Control } \\
\text { communication }\end{array}$ & $\begin{array}{l}\text { Rarely } \\
\text { delegate }\end{array}$ & $\begin{array}{l}\text { Zareen, Razzaq \& } \\
\text { Muitaba (2015) }\end{array}$ \\
\hline $\begin{array}{l}\text { Authentic } \\
\text { Leadership }\end{array}$ & $\begin{array}{l}\text { Draws from both } \\
\text { positive } \\
\text { psychological } \\
\text { capacities and } \\
\text { highly developed } \\
\text { organizational } \\
\text { context for leaders } \\
\& \text { associates. }\end{array}$ & $\begin{array}{l}\text { Self-awareness, } \\
\text { Relational } \\
\text { transparency, } \\
\text { Balanced processing } \\
\text { \& Internalized } \\
\text { Moral perspective }\end{array}$ & $\begin{array}{l}\text { Task-oriented, } \\
\text { Participatory, } \\
\text { Production- } \\
\text { motivated, } \\
\text { People-oriented, } \\
\text { Relationship- } \\
\text { motivated }\end{array}$ & $\begin{array}{l}\text { Open \& } \\
\text { transparent } \\
\text { communication }\end{array}$ & $\begin{array}{l}\text { Does } \\
\text { delegation }\end{array}$ & $\begin{array}{l}\text { Men \& Stacks } \\
(2014)\end{array}$ \\
\hline
\end{tabular}


Table 1 (continued...)

\begin{tabular}{|c|c|c|c|c|c|c|}
\hline $\begin{array}{l}\text { Spiritual } \\
\text { Leadership }\end{array}$ & $\begin{array}{l}\text { Emphasize } \\
\text { intrinsic } \\
\text { motivation } \\
\text { through a sense of } \\
\text { community due to } \\
\text { positive } \\
\text { interactions } \\
\text { between leader } \\
\text { and followers. }\end{array}$ & $\begin{array}{l}\text { Vision, Hope, faith, } \\
\text { Altruistic love \& } \\
\text { Spiritual anchors }\end{array}$ & $\begin{array}{l}\text { Participatory, } \\
\text { People- } \\
\text { motivated, } \\
\text { Relationship- } \\
\text { oriented, } \\
\text { Consideration } \\
\text { approach }\end{array}$ & $\begin{array}{l}\text { Open } \\
\text { Communication }\end{array}$ & $\begin{array}{l}\text { Does } \\
\text { delegate }\end{array}$ & $\begin{array}{l}\text { Youssef \& } \\
\text { Luthans (2012) }\end{array}$ \\
\hline $\begin{array}{l}\text { Servant } \\
\text { Leadership }\end{array}$ & $\begin{array}{l}\text { Focus on others } \\
\text { rather than self. } \\
\text { The goal is to } \\
\text { serve and meet the } \\
\text { needs of others. }\end{array}$ & $\begin{array}{l}\text { Developed people, } \\
\text { help people to strive, } \\
\text { Vision, Honesty, } \\
\text { Integrity, Trust, } \\
\text { Service, Modelling, } \\
\text { Pioneering, } \\
\text { Appreciation of } \\
\text { others, \& } \\
\text { Empowerment }\end{array}$ & $\begin{array}{l}\text { Participatory, } \\
\text { Empowering, } \\
\text { People-oriented, } \\
\text { Relationship- } \\
\text { motivated, } \\
\text { consideration } \\
\text { approach }\end{array}$ & $\begin{array}{l}\text { Open } \\
\text { Communication }\end{array}$ & $\begin{array}{l}\text { Does } \\
\text { delegate }\end{array}$ & $\begin{array}{l}\text { Stone, Russell \& } \\
\text { Patterson (2003); } \\
\text { Russell \& Stone } \\
(2002)\end{array}$ \\
\hline $\begin{array}{l}\text { Ethical } \\
\text { Leadership }\end{array}$ & $\begin{array}{l}\text { Fair and } \\
\text { principled } \\
\text { decision-makers } \\
\text { who care about } \\
\text { people and } \\
\text { society, behave } \\
\text { ethically in their } \\
\text { personal and } \\
\text { professional lives }\end{array}$ & $\begin{array}{l}\text { Moral person, Moral } \\
\text { manager, Fair } \\
\text { treatment, Power- } \\
\text { sharing, Role } \\
\text { clarification, } \\
\text { Integrity, Ethical } \\
\text { guidance \& } \\
\text { sustainability }\end{array}$ & $\begin{array}{l}\text { Participatory, } \\
\text { Directive, Task- } \\
\text { oriented, } \\
\text { People-oriented, } \\
\text { Relationship- } \\
\text { motivated, } \\
\text { Structure } \\
\text { approach }\end{array}$ & $\begin{array}{l}\text { Open \& Control } \\
\text { Communication }\end{array}$ & $\begin{array}{l}\text { Does } \\
\text { delegate }\end{array}$ & $\begin{array}{l}\text { Brown \& Trevino } \\
\text { (2016); Men } \\
\text { (2015) }\end{array}$ \\
\hline $\begin{array}{l}\text { Shared } \\
\text { Leadership }\end{array}$ & $\begin{array}{l}\text { An interactive } \\
\text { influence process } \\
\text { in a team in which } \\
\text { individuals take } \\
\text { turns to lead one } \\
\text { another to achieve } \\
\text { a common } \\
\text { purpose. A team- } \\
\text { based approach to } \\
\text { leadership rather } \\
\text { than solely by a } \\
\text { single designated } \\
\text { individual. }\end{array}$ & $\begin{array}{l}\text { Collaborative } \\
\text { decision making, } \\
\text { Shared } \\
\text { responsibility for } \\
\text { outcome \& } \\
\text { Openness to } \\
\text { reciprocal influence }\end{array}$ & $\begin{array}{l}\text { Participatory, } \\
\text { Empowering, } \\
\text { Task-oriented, } \\
\text { People-oriented, } \\
\text { Production- } \\
\text { motivated, } \\
\text { Relationship- } \\
\text { motivated }\end{array}$ & $\begin{array}{l}\text { Open \& } \\
\text { transparent } \\
\text { Communication }\end{array}$ & $\begin{array}{l}\text { Highly } \\
\text { delegate }\end{array}$ & Hoc (2013) \\
\hline
\end{tabular}

Whereas in table 2, various leadership styles are presented and their relationship with communication tolerance and delegation tolerance from previous researchers.

Table 2: Style of Leadership

\begin{tabular}{|c|c|c|c|c|c|c|}
\hline $\begin{array}{l}\text { Leadership } \\
\text { style }\end{array}$ & Meaning & Characteristics & Approach & $\begin{array}{l}\text { Tolerance of } \\
\text { communication }\end{array}$ & $\begin{array}{l}\text { Tolerance } \\
\text { of } \\
\text { delegation }\end{array}$ & $\begin{array}{l}\text { Author \& } \\
\text { Year }\end{array}$ \\
\hline $\begin{array}{l}\text { Autocratic } \\
\text { Leadership }\end{array}$ & $\begin{array}{l}\text { An exploitative- } \\
\text { authoritative } \\
\text { system where } \\
\text { power and } \\
\text { direction come } \\
\text { from the top } \\
\text { downwards, } \\
\text { threat and } \\
\text { punishment } \\
\text { common. }\end{array}$ & $\begin{array}{l}\text { Authority, Control, } \\
\text { Power play, } \\
\text { Manipulation, } \\
\text { Commanding, } \\
\text { Punishment, Formal } \\
\text { centralized structures }\end{array}$ & $\begin{array}{l}\text { Directive, Task- } \\
\text { oriented, } \\
\text { production- } \\
\text { motivated, } \\
\text { Structure } \\
\text { approach }\end{array}$ & $\begin{array}{l}\text { Closed \& } \\
\text { Control } \\
\text { communication }\end{array}$ & $\begin{array}{l}\text { Rarely } \\
\text { delegates }\end{array}$ & $\begin{array}{l}\text { Fiaz, Su, Ikram } \\
(2017) ; \\
\text { Goleman, } \\
\text { Boyatzio \& } \\
\text { McKee (2002) }\end{array}$ \\
\hline $\begin{array}{l}\text { Democratic } \\
\text { Leadership }\end{array}$ & $\begin{array}{l}\text { Focus more on } \\
\text { people, greater } \\
\text { interaction } \\
\text { within the } \\
\text { group. } \\
\text { Responsibilities } \\
\text { shared with } \\
\text { membership } \\
\text { and leader part } \\
\text { of a team }\end{array}$ & $\begin{array}{l}\text { Friendly, Helpful, } \\
\text { Encourage } \\
\text { Participation, } \\
\text { Benevolent, Teamwork } \\
\text { \& Collaborative }\end{array}$ & $\begin{array}{l}\text { Participative, } \\
\text { Task-oriented, } \\
\text { People-oriented, } \\
\text { Relationship- } \\
\text { motivated, } \\
\text { consideration } \\
\text { approach }\end{array}$ & $\begin{array}{l}\text { Open \& } \\
\text { Transparent } \\
\text { communication }\end{array}$ & $\begin{array}{l}\text { Does } \\
\text { delegate }\end{array}$ & $\begin{array}{l}\text { Fiaz, Su, Ikram } \\
(2017) ; \\
\text { Goleman, } \\
\text { Boyatzio \& } \\
\text { McKee (2002) }\end{array}$ \\
\hline
\end{tabular}




\begin{tabular}{|c|c|c|c|c|c|c|}
\hline $\begin{array}{l}\text { Visionary } \\
\text { Leadership }\end{array}$ & $\begin{array}{l}\text { Moves people } \\
\text { towards shared } \\
\text { dreams, leader } \\
\text { help people to } \\
\text { see how their } \\
\text { work fit into the } \\
\text { big picture }\end{array}$ & $\begin{array}{l}\text { Inspirational, } \\
\text { Charismatic, Articulate } \\
\& \\
\text { Sensitive towards } \\
\text { others }\end{array}$ & $\begin{array}{l}\text { Participatory, } \\
\text { Empowering, } \\
\text { People- } \\
\text { oriented, Task- } \\
\text { oriented, } \\
\text { Relationship- } \\
\text { motivated } \\
\end{array}$ & $\begin{array}{l}\text { Open } \\
\text { communication }\end{array}$ & $\begin{array}{l}\text { Does } \\
\text { delegate }\end{array}$ & $\begin{array}{l}\text { Goleman, } \\
\text { Boyatzio \& } \\
\text { McKee (2002) }\end{array}$ \\
\hline $\begin{array}{l}\text { Coaching } \\
\text { Leadership }\end{array}$ & $\begin{array}{l}\text { Focuses on } \\
\text { development } \\
\text { rather than } \\
\text { accomplishing } \\
\text { the task }\end{array}$ & $\begin{array}{l}\text { Establish rapport \& } \\
\text { trust, Emotionally } \\
\text { sensitive, Delegate, } \\
\text { Highly supportive }\end{array}$ & $\begin{array}{l}\text { Empowering, } \\
\text { Participatory, } \\
\text { People- } \\
\text { oriented, } \\
\text { Relationship- } \\
\text { motivated, } \\
\text { Consideration } \\
\text { approach }\end{array}$ & $\begin{array}{l}\text { Open \& } \\
\text { transparent } \\
\text { communication }\end{array}$ & $\begin{array}{l}\text { Does } \\
\text { delegate }\end{array}$ & $\begin{array}{l}\text { Goleman, } \\
\text { Boyatzio \& } \\
\text { McKee (2002) }\end{array}$ \\
\hline $\begin{array}{l}\text { Affiliative } \\
\text { Leadership }\end{array}$ & $\begin{array}{l}\text { Leadership } \\
\text { values people } \\
\text { and their } \\
\text { feelings, give } \\
\text { emotional } \\
\text { support to } \\
\text { followers and } \\
\text { work towards } \\
\text { accomplishing } \\
\text { the task }\end{array}$ & $\begin{array}{l}\text { Keep people happy, } \\
\text { emphasize harmony, } \\
\text { Build team resonance } \\
\& \text { Value and respect } \\
\text { others }\end{array}$ & $\begin{array}{l}\text { Participatory, } \\
\text { Empowering, } \\
\text { people-oriented, } \\
\text { Relationship- } \\
\text { motivated, } \\
\text { Task-oriented }\end{array}$ & $\begin{array}{l}\text { Open } \\
\text { communication }\end{array}$ & $\begin{array}{l}\text { Does } \\
\text { delegate }\end{array}$ & $\begin{array}{l}\text { Goleman, } \\
\text { Boyatzio \& } \\
\text { McKee (2002) }\end{array}$ \\
\hline $\begin{array}{l}\text { Pace-setting } \\
\text { Leadership }\end{array}$ & $\begin{array}{l}\text { Sets a high } \\
\text { standard of } \\
\text { performance } \\
\text { and is obsessive } \\
\text { about doing } \\
\text { things better } \\
\text { and faster }\end{array}$ & $\begin{array}{l}\text { Focus on goals/ results, } \\
\text { Excessive demands, } \\
\text { Intolerant to laziness, } \\
\text { Good time } \\
\text { management, } \\
\text { Commanding \& } \\
\text { Control }\end{array}$ & $\begin{array}{l}\text { Directive, Task- } \\
\text { oriented, } \\
\text { Production- } \\
\text { motivated, } \\
\text { Structure } \\
\text { approach }\end{array}$ & $\begin{array}{l}\text { Close \& Control } \\
\text { Communication }\end{array}$ & $\begin{array}{l}\text { Rarely } \\
\text { delegate }\end{array}$ & $\begin{array}{l}\text { Goleman, } \\
\text { Boyatzio \& } \\
\text { McKee (2002) }\end{array}$ \\
\hline
\end{tabular}

From the results of the extraction of the two tables, there is no prohibition regarding the prerogative of the leader as to what kind of delegation, when to delegate, and to whom the delegation is. Delegation provides space for leaders to pay attention to more challenging responsibilities. Client et.al (2006), in their study of dynamic delegation, argues that leaders can make rapid and repetitive delegation of leadership responsibilities to subordinates and can revoke that mandate in response to changing task demands. This implies that leadership can delegate but cannot yet determine whether communication falls into that category. Much of the research is widely agreed that leadership can delegate tasks that are a single identifiable activity. Communication is mostly labeled as process, function, responsibility, and skill according to several papers and therefore it is not clear whether communication can be delegated. Leadership and communication are marriage because the type of leadership or leadership style will determine the communication style to be used. Today because of the heterogeneous nature of employees in organizations, one type, one style or one fits all approach will never work in line with the doctrines of the theory $\mathrm{X}$ and the theory of $\mathrm{Y}$ employees. Today's demands challenge effective and efficient leaders to adopt a style or 
combination of styles that are considered appropriate for certain situations (Zulch, 2014). The combination of these factors influences the delegated nature of leadership.

De Vries, Bakker-Pieper \& Oosteveld (2010), stated that a people-oriented or relationship-motivated leadership approach is much more communicative than a taskoriented or production-motivated approach to leadership. They connect the leadership style with the leader's interpersonal communication style.

\section{RESEARCH METHOD}

The purpose of this study is to identify, explore, explain and build relationships whether or not leadership should delegate communication in relational interactions between leaders and subordinates. This study uses a Systematic Literature Review (SLR). The inclusion criteria in this study were:

1. Using the keywords "communication", "delegation" and "leadership"

2. Data is taken from various sources, namely Google scholar, Researchgate, Emerald, Science Direct, Sage Publications, Elsevier, Scopus, and Web of Science.

3. Data is limited between 1990 - 2019, including journal articles, books, and book chapters.

\section{RESEARCH RESULTS AND DISCUSSION}

From the processing results, 28 articles were obtained according to the criteria as shown in the following figure:

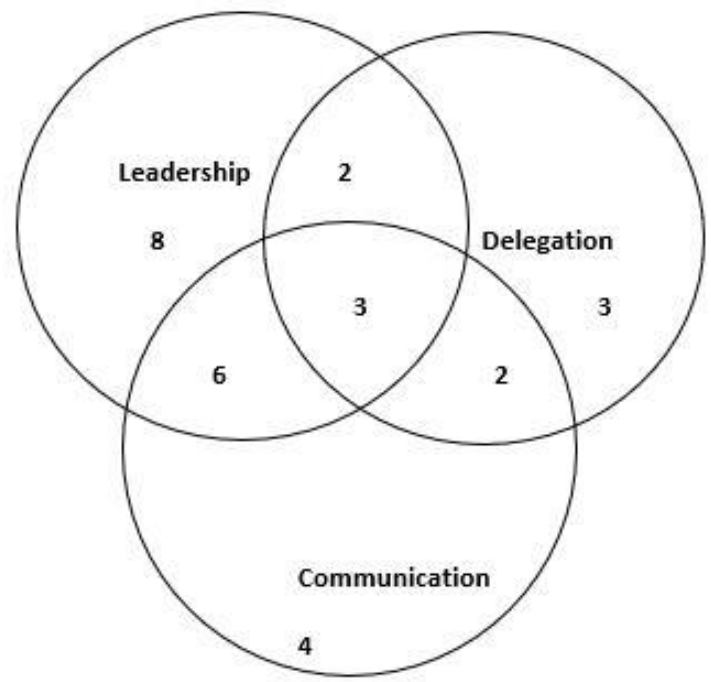

Figure 1: Number of articles per subject (theoretical argument)

From the picture, it can be seen that 8 articles specifically discuss leadership, 3 articles discuss delegation, and 4 articles specifically discuss communication. There are 3 articles based on all keywords, 6 articles for leadership and communication keywords, 2 articles for leadership and delegation, and 2 articles for delegation and communication keywords.

From the selection process and inclusion criteria in the selected articles, it appears that the researchers state that there is no limit to whether the delegation of leadership should or should not be. However, most researchers agree that tasks are easy to delegate because they are identifiable and implementable activities. Delegation as a leader's prerogative is given to someone who has the knowledge and ability to perform tasks. 
This study also found that communication is broadly and ambiguously represented as tasks, skills, processes, functions, and as leadership responsibilities.

Communication is not clearly defined as a delegation. But the role of the spokesperson certainly represents only the transfer of the burden from the leader to a third party. The role of the spokesperson is very important for leadership communication efforts because it will make it easier for the spokesperson to step in when the leader is not around. But such assignments are limited to few talking points to fill gaps. In most political situations, often leaders delegate some policy information to spokespersons to avoid backlash and error if a safe face and political office are wrong.

It is also agreed that in the chain of command in organizational decision-making structures, supervisors act as a buffer between low employee rankings and officials. Often, supervisors are delegated with various levels of authority to assist leaders in completing tasks and jobs according to the leadership's wishes.

Delegation of leadership and communication depends on the type and style of leadership which also determines what form of delegation or communication will be received. The type of leadership and leadership style will determine the level of tolerance of communication.

\section{E. CONCLUSION}

This Research can add new thinking to leadership in the context of communication and delegation. The nature of leadership today is very unpredictable and no single approach is most appropriate. Leadership is determined by decision making but there is a fine line to distinguish whom the decision serves, whether it is leadership or followers who place and trust the leader to achieve a common goal.

Rational and objective decision-making cannot occur without the sharing of complete and factual information that is not mixed with individual interests. Effective and mutually controlled communication is a manifestation of leadership to build trust and create ways to collaborate with others in a collegial climate to achieve results. Today's leadership is so confusing that some prefer a mix of leadership styles and approaches as the only way out of bias and compromise. The implication of this research is as a guide for leaders to know what to delegate concerning communication, policy information and to take responsibility whatever the outcome. Also, so that leaders know that not everyone can communicate by knowing what to say and how to say it.

\section{REFERENCES}

Axley, S., R. (1992). Delegate: Why we Should, why we don't and How we can, ABI/INFORM COLLECTION, Industrial Management, Vol. 34, (5), pg.1-16

Ayres, W., R. (1992). Management: mastering the Fine Art of Delegation, Black Enterprises, Vol. 22 (9), pg. 1-10

Badjie, G. Thoyib, A., Hadiwidjojo, D., Rofiq, A. (2019). The Search for New New Measures in Organisational Communication: A systematic Literature Review, Humanities \& Social Sciences Reviews, Vol. 7, (1), pp. 469-477 
Berger, B. (2008). Employee/organizational communication. Institute for Public Relations. Gainesville, FL. Institute for Public Relations, Retrieved from; http://www.instituteforpr.org/topics/employee-organizational-communications/

Brown, E., M. \& Trevińo, L., K. (2006). Ethical leadership: A Review and Future Directions, The leadership Quarterly, Iss. 17, pp. 595-616

Constantin, A., \& Petrućia, I. (2019). The Role of the Spokesperson in the Process of Public Relations, International Journal of Communication Research, Vol.9, (3), pp.261-265

David, D. (2016). Delegation, A Powerful Tool, By HR.com, (ABI? INFORM Collection) Leadership Excellence essentials, Vol. 33 (3), pg.1-18

De vries, R., E., Bakker-Pieper, A. \& Oostenveld, W. (2010). Leadership = Communication? The Relations of Leaders' Communication Styles with Leadership Styles, Knowledge Sharing and Leadership Outcomes, Journal of Business Psychology, Vol. 25, pp.367-380

Dessein, W. (2002). Authority and Communication in Organisations, The Review of Economic Studies, Vol. 69, (4), pp. 811-838

Fiaz, M., Su, Q. \& Ikram, A. (2017). Leadership Styles and Employees' Motivation: Perspective from an Emerging Economy, The Journal of Developing Areas, Vol. $51(4)$

Garofolo, O. \& Rott, C. (2017). Shifting Blame? Experimental Evidence of Delegating Communication, Management Science, Vol. 64 (8), pp 3911-3925

Goleman, D., Boyatzis, R., \& McKee, A. (2002). The New Leaders: Transforming the Art of Leadership into the Science of Results. London: Little, Brown

Hamrin, S., Johansson, C. \& Jahn, J. L. S. (2016). Communicative Leadership: Fostering Co-worker Agency in two Swedish Business Organisations, Corporate Communications: An International Journal, Vol. 21, (2), pp. 213-229

Hoc, J., E. (2013). Shared Leadership and Innovation: The Role of Vertical leadership and Employee Integrity, Journal of Business Psychology, Vol. 28, pp.159-174

Hon, L., C. \& Grunig, J., E. (1999). Guidelines for Measuring Relationship in Public Relations. Gainesville, FL: Institute for Public Relations, Commission on PR Measurement and Evaluation

Jones, E., Watson, B., Gardner, J. \& Gallois, C. (2004). Organizational Communication: Challenges for the New Century, Journal of Communication, Vol. 54 (4), pp. 722750 
Klein, K., J., Ziegert, J. C., Knight, A. P. \& Xiao, Y. (2006). Dynamic Delegation: Shared Hierarchical and Deindividualized Leadership in Extreme Action Teams, Administrative Science Quarterly, Vol. 51 (4), pp.590-621

Kovač, J. \& Jesenko, M. (2010). The Connection between Trust and Leadership Styles in Slovene Organisations, Journal of East European Management Studies, Vol. 15, (1), pp. 9-33

Men, L., R. (2014). Strategic Internal Communication: Transformational Leadership, Communication Channels, and Employee Satisfaction, Management Communication Quarterly, Vol. 28, (2), pp. 264-284

Men, L., R. (2015). The Role of Ethical Leadership in Internal Communication: Influences on Communication Symmetry, Leader Credibility and Employee Engagement, Journal of Public Relations Research, Vol. 9, (1), pg. 1-22

Men, L., R. \& Stacks, D., W. (2014). The Effects of Authentic Leadership and Strategic Internal Communication and Employee-Organisation Relationship, Journal of Public Relations Research, Vol. 36, (4), pp. 301-324

Mintzberg, H. (1971). Managerial Work: Analysis from Observation, Management Science Journal, vol.18, B97-B110

Rousseau, D. M., Manning, J., \& Denyer, D. (2008). Evidence in Management and Organizational Science: Assembling the Field's Full Weight of Scientific Knowledge Through Syntheses. SSRN eLibrary. Retrieved from http://papers.ssrn.com/sol3/papers.cfm?abstract_id=1309606

Russell, R., F. \& Stone, A., G. (2002). A review of Servant leadership Attributes: Developing a Practical Model, Leadership, Organisation Development Journal, Vol. 23, (3), pp. 145-157

Stone, A., G., Russell, R., F. \& Patterson, K. (2003). Transformational versus servant leadership: A Difference in Leader Focus, Servant Leadership Research Roundtable, pg. 1-10

Youssef, C. M. \& Luthans, F. (2012). Positive Global Leadership, Journal of World Business, Vol. 47, pp. 539-547

Yukl, G. \& Fu, P., P. (1999). Determinants of Delegation and Consultation by Managers, Journal of Organisational Behaviour, Vol. 20, pp. 219-232 
Zarren, M., Razzaq, K. \& Muitaba, B., G. (2015). Impact of Transactional, Transformational and Laizzez-Faire Leadership Styles on Motivation: A Quantitative Study of Banking Employees in Pakistan, Public organizations Review, Vol. 15 (15), pp. 531-549

Zulch, B. (2014). Leadership Communication in Project Management, Procedia-Social, and Behavioural Sciences, Vol. 119, pp.172-181 